\title{
Establishment of a new genus for Parastenocaris itica (Copepoda, Harpacticoida) from El Salvador, Central America, with discussion of the Parastenocaris fontinalis and $P$. proserpina groups
}

\author{
Paulo Henrique C. Corgosinho ${ }^{1,2}$, Pedro Martínez Arbizu ${ }^{3,4} \&$ Daniel Previattelli²
}

\footnotetext{
1. Center Unesco/HIDROEX (International Center for Education, Capacity Building and Applied Research in Water), Av. Mário Palmério, 1000, Bairro Universitário, 38200-000, Frutal, MG, Brazil. (pcorgo@gmail.com; paulo.corgosinho@hidroex.mg.gov.br)

2. Universidade Estadual de Minas Gerais (UEMG), Av. Mário Palmério, 1001, Bairro Universitário, 38200-000, Frutal, MG, Brazil.

3. Forschungsinstitut Senckenberg, Senckenberg am Meer, Dept. DZMB (Deutsches Zentrum für Marine Biodiversitätsforschung), Südstrand 44, 26382 Wilhelmshaven, Germany.

4. Fakultät V, Institut für Biologie und Umweltwissenschaften, Universität Oldenburg, Oldenburg, Germany.
}

\begin{abstract}
A new genus of Parastenocarididae is described from the Neotropical region. Iticocaris gen. nov. is established to include Parastenocaris itica Noodt, 1962. Iticocaris gen. nov. is defined by the following characters: 1) male leg 3 with 2-segmented exopod; 2) first exopodal segment short and rectangular; 3 ) thumb hypertrophic, longer than the second exopodal segment and inserted on the distal edge of exopod segment 1 , occupying the whole distal margin; 4) exopod 2 or apophysis strongly sclerotized, articulated with the exopod segment 1 on its inner margin and curved against the thumb, forming a strong forceps; 5) leg 4 endopod without dimorphism in shape and size vs. minor dimorphism in ornamentation; 6) leg 5 with three setae and 7) lack of the anterolateral furcal seta II. The new genus is monotypic, represented by Iticocaris itica (Noodt, 1962) comb. nov., from El Salvador, Central America. A close relationship is hypothesized between I. itica and the genus Brasilibathynellocaris Jakobi, 1972, the males of which both share the forceps-like elongated apophysis.
\end{abstract}

KEYWORDS. Freshwater, Neotropics, Parastenocarididae, Taxonomy.

RESUMO. Proposta de um novo gênero para Parastenocaris itica (Copepoda, Harpacticoida) de EI Salvador, América Central e discussão dos grupos Parastenocaris fontinalis e P. proserpina. Um novo gênero de Parastenocarididae é proposto para a Região Neotropical para incluir Parastenocaris itica Noodt, 1962. Iticocaris gen. nov. é diagnosticado pela presença dos seguintes caracteres: 1) toracópodo 3 do macho com exópodo bissegmentado; 2) primeiro segmento exopodal curto e retangular; 3) "thumb" hipertrófico, mais longo que o segundo segmento do exópodo e inserido na margem distal do exópodo 1, ocupando toda a margem distal do segmento; 4) exópodo 2 ou apófise fortemente esclerotizado, articulado com o exópodo 1 em sua margem interna e curvado contra o "thumb", formando um forte fórceps; 5) endópodo do toracópodo 4 sem dimorfismo sexual quanto à forma e tamanho vs. discreto dimorfismo quanto à ornamentação; 6) toracópodo 5 com três cerdas e 7) furca sem a cerda anterolateral II. O novo gênero é monotípico, sendo representado por Iticocaris itica (Noodt, 1962) comb. nov., proveniente de El Salvador na América Central. É hipotetizado que I. itica e o gênero Brasilibathynellocaris Jakobi, 1972 sejam próximos filogeneticamente, possuindo os machos de ambos os gêneros uma apófise alongada e "thumb" formando uma estrutura similar a um fórceps.

PALAVRAS-CHAVE. Água doce, Neotropical, Parastenocarididae, Taxonomia.

The family Parastenocarididae (Copepoda, Harpacticoida) is a diverse group of freshwater interstitial microcrustaceans, with approximately 250 described species worldwide (SCHMINKe, 2010). Until recently, this family was represented by only a few accepted genera: Parastenocaris Kessler, 1913; Forficatocaris Jakobi, 1969; Paraforficatocaris Jakobi, 1972; Potamocaris Dussart, 1979; Murunducaris Reid, 1994, and Simplicaris Galassi \& De Laurentiis, 2004. This view has gradually changed, with new genera being established or revalidated in the recent literature (Corgosinho \& Martínez Arbizu, 2005; Corgosinho et al., 2010; CotTarelli et al., 2010; Galassi \& De LaURENTiIs, 2004; SchminKe, 2008, 2009; KARANOvic \& COOPER, 2011).

It is therefore, undeniable that the most diverse genus Parastenocaris is a "taxonomic repository" being composed by species belonging to different phylogenetic lineages, not closely related to each other. Therefore this genus as a whole is in urgent need of profound revision. The taxonomic confusion around the type-genus of the family is further complicated by the subsequent synonymies established, as for example for the genus Biwaecaris Jakobi, 1972 which has been synonymized with Parastenocaris by ReID (1995). Moreover, according to SCHMinke (2010), it is not unlikely that members of Brinckicaris Jakobi, 1972, Enckellicaris Jakobi, 1972, and Oshimaensicaris Jakobi, 1972 should be moved to the genus Parastenocaris, entering the Parastenocaris brevipes group, as defined by REID (1995), and subsequently supported by GALASSI \& DE LAURENTIIS (2004) and KARANOVIC $(2005,2006)$. For a discussion of the taxonomy within the genus Parastenocaris see ReID (1995), Galassi \& De LaurentiIs (2004) and Karanovic \& LEE (2012).

In the last few years, Parastenocarididae has undergone significant systematic and taxonomic modifications. Three new genera, Monodicaris Schminke, 2009, Asiacaris Cottarelli, Bruno \& Berera, 2010, Dussartstenocaris Karanovic \& Cooper, 2011 and two new subfamilies have been recently established (Schminke, 2010). Furthermore, Corgosinho \& Martínez Arbizu (2005) and CorgosinHo et al. (2007) proposed the adoption of all the genera described by JAKOBI (1972a,b) which are available according to the ICZN (1999) (articles 11.5, 13, 67.8 and 68), pending a deep revision for assessing the monophyly of these genera. Towards a better understanding of the systematics of the family as 
a whole, Remaneicaris Jakobi, 1972 was redefined by Corgosinho \& Martínez Arbizu (2005), Siolicaris Jakobi, 1972 was redefined by CorgosinHo et al. (2012), while SCHMINKE (2008) synonymized Cafferocaris Jakobi, 1972 with Kinnecaris Jakobi, 1972, arguing in favor of the monophyly of Kinnecaris. Recently, Paraforficatocaris and Pararemaneicaris Jakobi, 1972 were relegated to junior synonyms of Brasilibathynellocaris Jakobi, 1972 when their type species were transferred to this genus (Corgosinho et al., 2010). The former Pararemaneicaris santaremensis (Noodt, 1963) is temporarily accommodated into Parastenocaris sensu lato as Parastenocaris santaremensis Noodt, 1963. Neotropical parastenocaridids are highly diversified and split into several monophyletic endemic groups, viz., Potamocaris, Forficatocaris, Murunducaris, Brasilibathynellocaris, Remaneicaris, and the Parastenocaris columbiensis group proposed by NoodT (1972). Although 77 species are described from the neotropics, the taxonomic diversification in this area is likely higher than presently known. For example, samples taken with different methods have provided several new species for a single sampling site (see ReID, 1993a,b; Corgosinho \& Martínez Arbizu, 2005; Corgosinho et al., 2007). It is not uncommon to find $3-4$ new species belonging to different parastenocaridid genera in samples taken by the Karaman-Chappuis method (CHAPPUIS, 1942), or other sampling devices, such as corers and kick nets.

Considering the biogeographical history of the Neotropical region and the high diversity of other taxa in this area, the fauna of parastenocaridids is potentially richer in the Central America, probably including representatives coming also from both the Holarctic region and from South America.

As a step towards a revision of Neotropical parastenocaridids, a new genus is proposed herein for Parastenocaris itica from Central America, and its phylogenetic position within the family is briefly discussed.

\section{MATERIALS AND METHODS}

Specimens have been analyzed from the Noodt's collection deposited at the Senckenberg am Meer, Dept. DZMB (Deutsches Zentrum für Marine Biodiversitätsforschung; "German Centre for Study of Marine Biodiversity"). For the description of $P$. itica, Noodt (1962) did not fix the holotype, only mentioned which samples came from the type-locality and postulated other locations, where $P$. itica was plausibly present. He mentioned 5 females and 8 males from the type-locality. However, our inspection of his collection revealed only 6 male and 3 females in the slides from the type-locality. Only a single slide containing 2 females and 2 males (some of them dissected) was properly labeled as Parastenocaris itica Noodt, 1962 (Box 7, slide 10, S332 taken from Rio Acehuafa, El Salvador).

In the past, it was a common practice, adopted also by Noodt and other researchers, to mount several specimens on a single slide, sometimes of different sexes, and with more than one specimen dissected and mounted together. Following the ICZN (1999) recommendation $73 \mathrm{~F}$, it is possible that the nominal species-group taxon was based on more than one specimen from the sample S64. In order to avoid designation of syntypes for $P$. itica, a dissected male from a multi-specimen preparation has been selected as lectotype (box 6 , slide 5, S64). The illustration of the habitus is based on an undissected male from the sample S332. The identification of all other specimens was confirmed by direct comparison with the lectotype (for males) and with the original illustrations (for females and males) as given by NoODT (1962).

Drawings were made under a microscope, fitted with Nomarski interference contrast optics and a drawing tube, at 400x and 1000x magnification.

The terms furca and telson are used according to Schminke (1976). The term thumb refers to the outer spine of the male swimming leg 3. This structure is homologous to the outer spine of the first segment of leg 3 exopod of the male copepodite $\mathrm{V}$ and females. The term apophysis refers to the second segment of swimming leg 3 exopod, which appears to be fused to the first exopodal segment in most species of Parastenocarididae. For details of the development of swimming leg 3 in males and the homologization of structures, see Glatzel (1991). The terms seta, setules, spines and spinules are used according to HuYs \& Boxshall (1991). Terminology and homologies of maxillary and maxillipedal structures follow FERRARI \& IVANENKO (2008). The term "groundpattern" is used in the acceptation of the German term "Grundmuster" (Ax, 1984).

When necessary, Noodt's collection was examined to compare seemingly similar features in P. itica, Brasilibathynellocaris species and other Parastenocarididae.

Abbreviations used: A1, antennule; A2, antenna; $\mathrm{Ae}$, aesthetasc; ap, apomorphy; $\mathrm{Cph}$, cephalothorax (includes cephalon and thoracic somites 1 and 2); enp, endopod; enp-1-3,endopodal segment 1-3; exp, exopod; exp-1-3, exopodal segments 1-3; Md, mandible; Mx1, Maxillule; Mx2, Maxilla; Mxp, maxilliped; P1-P6, swimming legs 1-6; pl, plesiomorphy.

\section{SYSTEMATICS}

\section{Parastenocarididae, Fontinalicaridinae Iticocaris gen. nov.} monotypy.

Type species: Iticocaris itica (Noodt, 1962), by

Synonyms: Parastenocaris itica Noodt, 1962; Remaneicaris itica Jakobi (1972).

Diagnosis. 8-segmented A1 in male (pl) and 7-segmented A1 in female (pl). Male A1 haplocer (pl). 
Basis of Mx2 with 2 endites, proximal endite with 1 seta ( $\mathrm{pl})$, distal endite with 3 elements ( $\mathrm{pl})$, one of them transformed into a serrated spine (pl); proximal endopodal segment drawn out into a claw, distal endopodal segment with 2 setae. Basis of P1 without sexual dimorphism (pl); enp not sexually dimorphic (pl). P2 enp without marked sexual dimorphism (pl). Male P3 with 2-segmented exp (ap). Exp-1 short, rectangular (ap), with a large tube pore on the inner margin (ap). Thumb hypertrophic longer than exp-2 (ap) and inserted on the distal edge of exp-1 (ap), occupying the whole distal margin (ap). Exp-2 or apophysis strongly chitinized (ap), articulating with exp-1 on its inner margin (ap) due to the hypertrophy of the thumb and its distal insertion; strongly curved against the thumb (ap) to form a strong forceps-like structure (ap); smooth on the inner margin and with a pronounced invagination in its proximal third (ap), on the outer concave margin. Presence of an uncinate process of unclear nature (rudimentary endopod?) on the inner margin of basis (ap). P4 enp not sexually dimorphic in shape (ap) but dimorphic in minor ornamentation. P5 triangular, with an outer basal seta and 2 setae located close to the inner spiniform process ( $\mathrm{pl}$ ?). Caudal rami with anterolateral setae (setae I, III) located close to the dorsal seta (seta VII, pl); seta II absent (pl). P6 represented by a naked opercular plate covering the genital opening (pl).

Type material. Lectotype, Wilhelmshaven, box 6 (slide 5, S64; dissected male) (examined). Paralectotypes, box 6 (slide 5, S64; 1 undissected male), box 6 (slide 6, S64; 2 dissected males and 2 undissected males), box 6 (slide 7, S64; 1 dissected female and 1 undissected female) (examined). Additional non-type material from box 7 (slide 10, S332; 2 females and 2 males).

Type locality. Large "Barranco" Tovar, near the Instituto Tropical in San Salvador, El Salvador. Groundwater samples were taken in a coarse sand ground, at a depth of $20 \mathrm{~cm}$.

Etymology. The generic name combines the specific epithet "itica" of the type species and the ancient Greek substantive for shrimp, кapis (caris).

Description. Male, length $440 \mu \mathrm{m}$ (measured by Noodt). Rostrum not fused to cephalothorax, with wide base and two sensilla on tip. Cephalothorax and Urs-24 with dorsal integumental windows (Fig. 1). Patterns of sensilla as in Fig. 1. Telson smooth, anal operculum smooth and convex (Fig. 1), as in female. Furca (Figs 1, 21) with distal pore and 6 setae; setae I and III located proximal to the seta VII; seta II absent. A1 8-segmented and prehensile (Fig. 3); armature, beginning by the proximal segment: 0/6/4/1/5+ae/3/2/9+ae. A2 as in female (Figs 16, 17), with allobasis; 1-segmented exp, with 1 seta, and 1-segmented enp bearing 7 setae. Labrum (Fig. 4) triangular, with a distal serrated zone. Md coxal gnathobasis (Fig. 5) with tooth-like attenuations and 1 seta, mandibular palp 1- segmented with 2 distal setae. Mx1 praecoxal arthrite (Fig. 6) with 5 elements (1

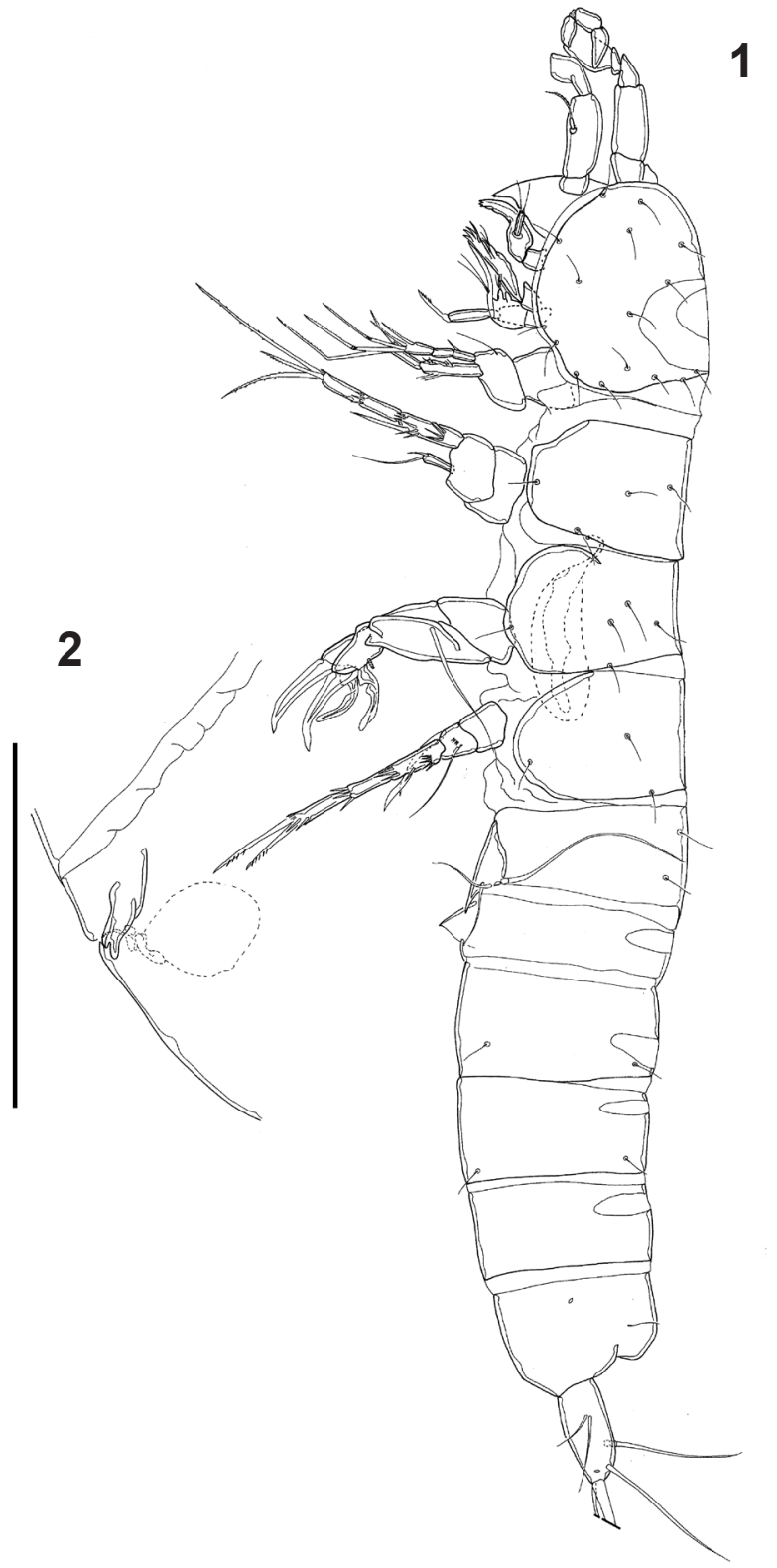

Figs 1, 2. Iticocaris itica (Noodt, 1962): 1, male, lateral habitus (Noodt collection, Box 7, slide 10; S332); 2, female, genital field, (Noodt collection, Box 6, slide 7; S64). Scale bar: Fig. 1, $100 \mu \mathrm{m}$; Fig. 2, $40 \mu \mathrm{m}$.

seta on dorsal surface, 3 claw-like pinnate spines and 1 slender seta), coxa with 1 seta, basis with 2 endites with 1 and 2 setae respectively. Mx2 basis (Fig. 7) with 2 endites, proximal endite with 1 seta, distal endite with three elements, one of them transformed into a serrated spine; proximal endopodal segment drawn out into a claw, distal endopodal segment with 2 setae. Mxp (Fig. 8) subchelate, composed of syncoxa, basis, 1-segmented endopod, and 1 claw-like apical seta. P1 (Fig. 9) coxa unarmed; basis with 1 outer seta, outer row of spinules, and distal row of small spinules; enp- 1 of the same size as the first 2 exopodal segments; exp 3-segmented, exp1 with outer spine, exp-2 unarmed, exp-3 with 2 outer spines and 2 geniculate setae; enp 2-segmented, enp-1 with 2 rows of large spinules on outer margin and an 
inner row of small spinules distally, enp- 2 with 1 outer spine, 1 geniculate seta, and a posterior hyaline frill. P2 (Fig. 10) coxa unarmed, with posterior row of spinules; basis lackingouter seta but ornamented with 1 row of spinules on outer margin; exp 3-segmented, exp-1 with long outer spine and with hyaline frill on inner margin; exp-2 lacking armature and with row of spinules of unequal size; exp-3 with 3 setae, a distal hyaline frill on the inner corner, and a row of long spinules on the outer margin; enp 1-segmented, with distal seta, distal spinule, 2 subdistal spinules, and 2 outer spinules in its medial portion. P3 (Fig. 11) coxa unarmed, with posterior row of spinules; basis large, with an inner uncinate process of unclear nature (enp remnant?); exp 2-segmented, exp1 short, rectangular, and with a large tube pore on inner margin, thumb hypertrophied (arrowed), longer than exp2 and inserting on the distal edge of exp-1, occupying the whole distal surface; exp-2 or apophysis strongly

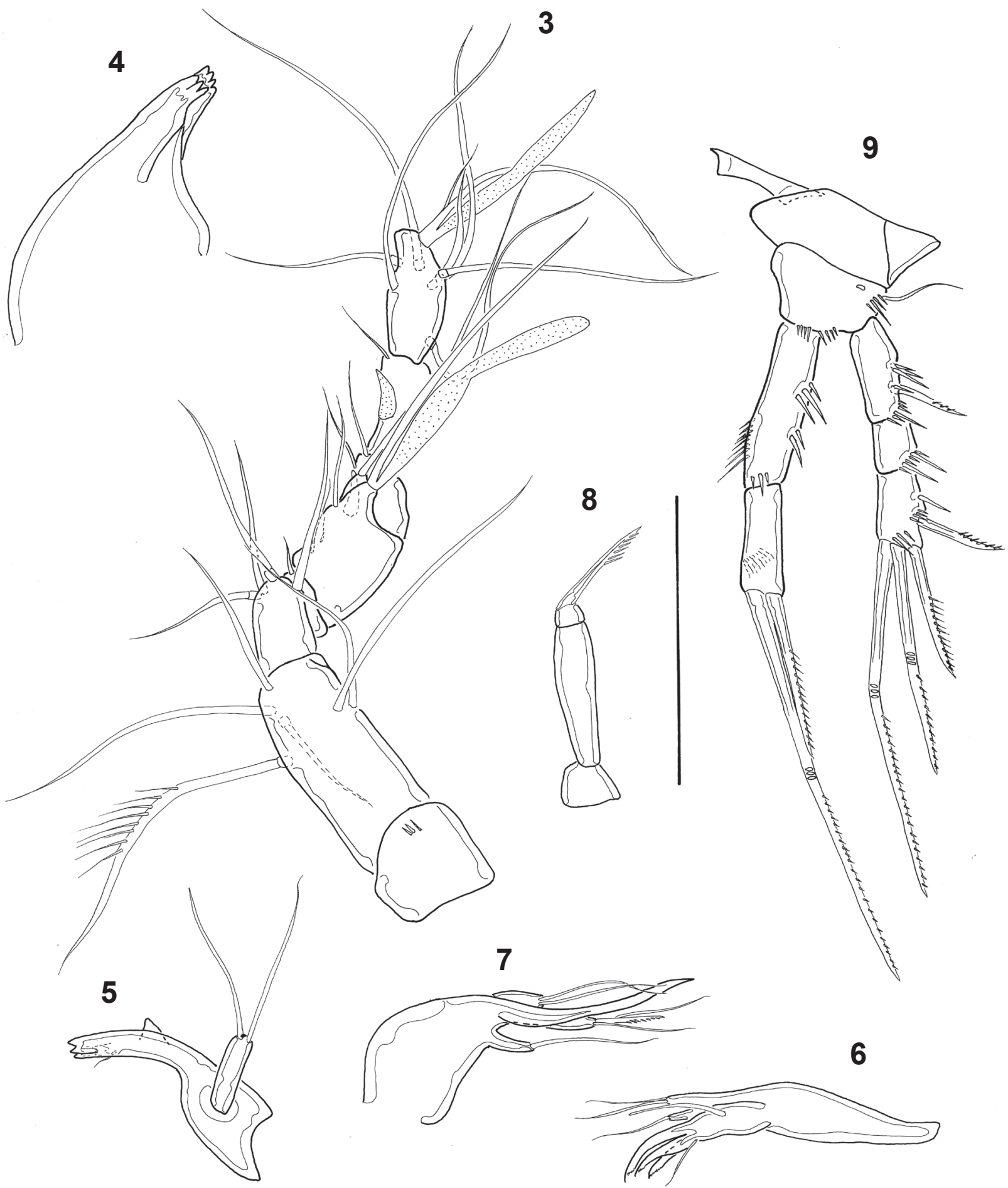

Figs 3-9. Iticocaris itica (Noodt, 1962), lectotype, Noodt collection, Box 6, slide 6; S64: 3, male A1; 4, labrum; 5, mandible; 6, maxillule; 7, maxilla; 8, maxilliped; 9, P1. Scale bar: $30 \mu \mathrm{m}$. 
10

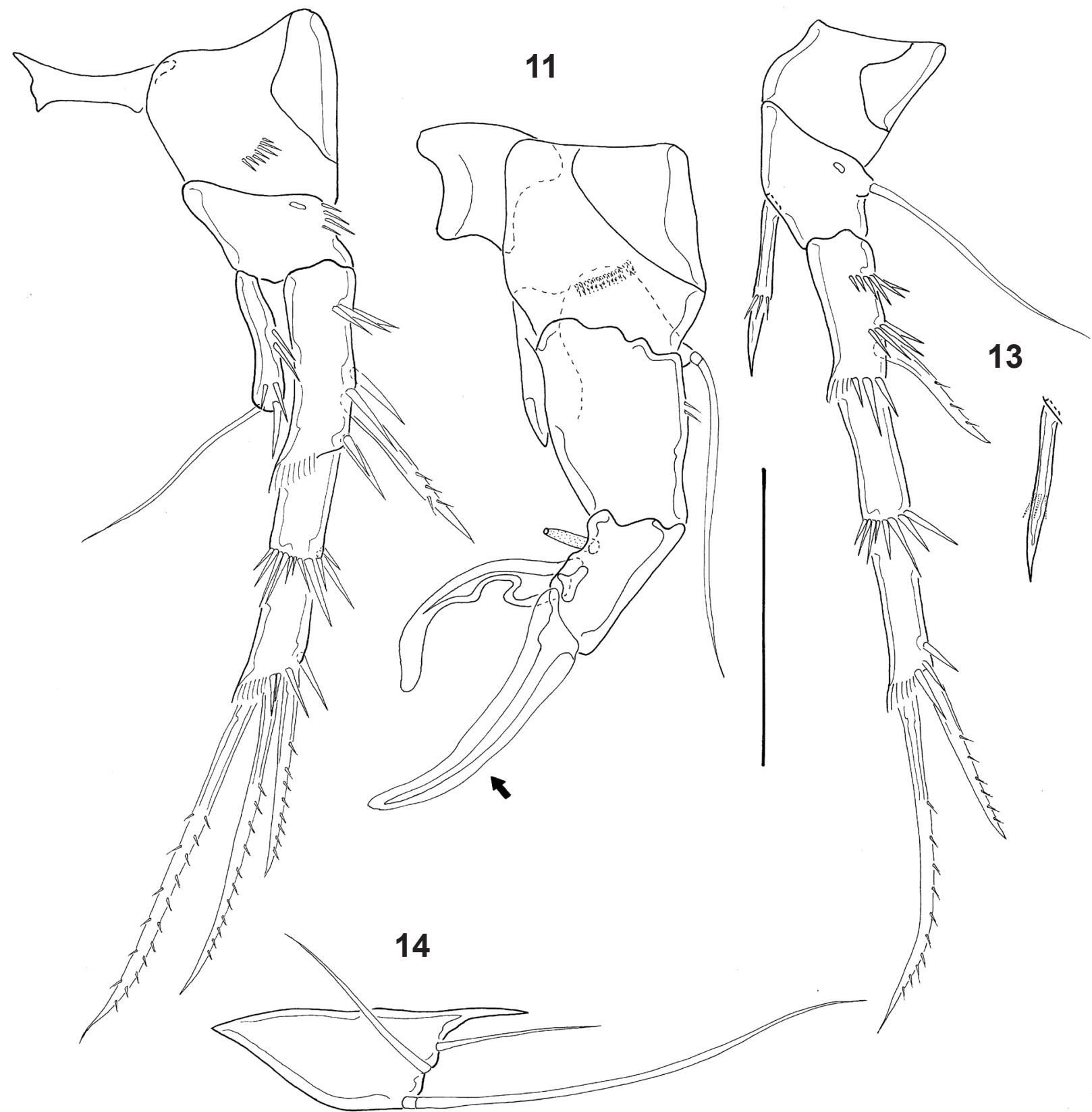

Figs 10-14. Iticocaris itica (Noodt, 1962), lectotype, Noodt collection, Box 6, slide 6: 10, male P2; 11, P3; 12, P4; 13, P5. Arrow indicates thumb. Scale bar $=30 \mu \mathrm{m}$.

sclerotized and curved towards thumb, to form a kind of strong, cheliform forceps; additionally, exp-2 smooth on the inner margin and with a pronounced invagination at proximal third of outer concave margin, articulating with the exp-1 on its inner margin of latter due to the hypertrophy of the thumb. P4 (Fig. 12) coxa unarmed; basis with outer seta and outer pore; exp 3-segmented, exp-1 with outer spine, exp-2 lacking armature and with row of distal spinules (smaller on inner margin), exp-3 with 2 setae and row of distal spinules on outer margin; enp spiniform (Figs 12, 13), straight and with a transverse row of spinules in its distal third (probably representing the border between the enp and fused distal seta); no sexual dimorphism in shape and only minor dimorphism in ornamentation. P5 triangular (Fig. 14), with an outer basal seta and 2 other setae between it and an inner spiniform process.

Female, length $443 \mu \mathrm{m}$ (measured by Noodt). Sexually dimorphic in A1, P2, P3 and genital doublesomite. Cephalothorax and Urs-2-4 with dorsal integumental windows. Telson smooth, anal operculum smooth and convex (Fig. 21). A1 7-segmented (Fig. 15); armature, beginning with proximal segment: 0/4/5/2+ae/1/1/9+ae. A2 (Figs 16, 17) with allobasis, 1-segmented exp with 1 seta, and 1-segmented enp bearing 7 setae. P2 (Fig. 18) exp not sexually dimorphic; 


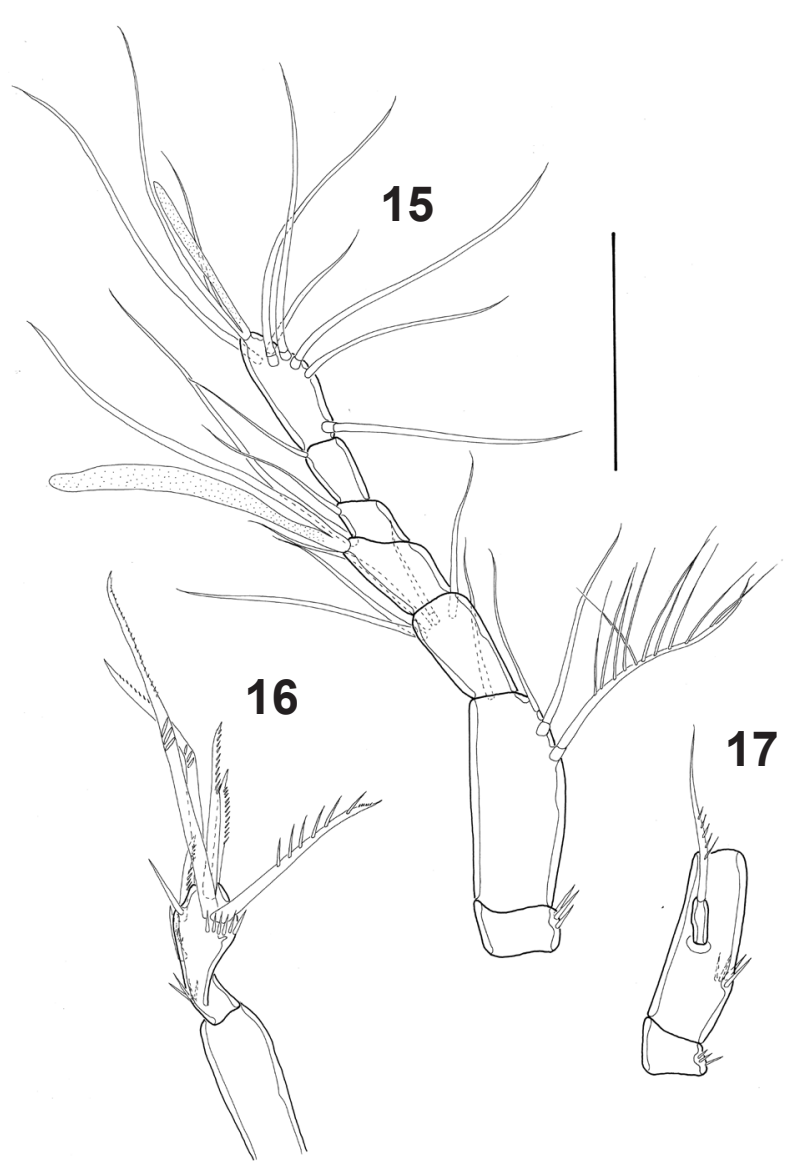

Figs. 15-17. Iticocaris itica (Noodt, 1962): 14, female A1 (paralectotype, Noodt collection, Box 6, slide 7); 15, 16: male A2 (syntype, Noodt collection, Box 6, slide 6). Scale bar: $30 \mu \mathrm{m}$.

enp with slight sexual dimorphism (slender and less ornamented in female). P3 (Fig. 19) coxa unarmed; basis with a long outer seta and an outer pore; enp represented by a short segment with 2 distal spinules; exp 2-segmented; exp-1 with an outer spine and an inner row of spinules distally; exp- 2 with 2 setae, an inner hyaline frill, and an outer row of spinules. P4 (Fig. 20) showing no sexual dimorphism in shape, but less ornamented than in the male. P6 (Fig. 2) consisting of paired unarmed genital flaps; U-shaped genital field.

\section{DISCUSSION}

Parastenocaris itica cannot be satisfactorily accommodated into any known LANG's (1948) groups of Parastenocarididae, or any other genus proposed in the family. Iticocaris gen nov. is herein established to accommodate this species and a detailed discussion supporting the establishment of a new taxonomic rank for this species is offered.

The phylogenetic position of $P$. itica instigated several discussions. According to Noodt (1962), the description of this species fitted the diagnosis given by LANG (1948) for the group of Parastenocaris fontinalis Schnitter \& Chappuis, 1915. However, comparison with the other species from this group revealed no particular similarity to any of them. Rejecting an assignment to this species group, NoodT (1962) instead hypothesized a possible close affinity with the group of Parastenocaris panamericana Noodt, 1962 (now Brasilibathynellocaris: see Corgosinho et al., 2010) due to similarities in P2, enp of female P3, female P4, P5, furca, and perhaps male P3; however, NoodT (1962) also remarked upon the lack in $P$. itica of the special characters observed in the P4 of males in this group (NoODT, 1962).

JAKOBI (1972a) included $P$. itica in Remaneicaris, which he defined by the presence of a male P3 exp long, thin, inwardly bent at a right angle or less, and frequently possessing an S-shaped thumb. These feature are, however, widespread in the family. Even within the genus Remaneicaris they appear independently in different monophyletic groups (P. H. C. Corgosinho, unpubl. data) and thus do not constitute part of the ground pattern of Remaneicaris. Rather, as was already noted by Corgosinho \& Martínez Arbizu (2005), P. itica could not be included in Remaneicaris due to its lack of the following autapomorphies of that genus: outer distal seta of P4 exp-3 located subdistally, intercoxal sclerite of P5 absent, and a medially inserted outer spinule present on exp-2 and exp-3 of legs 2 and 4.

Recently WeLLS (2007) listed P. itica as Remaneicaris itica but with no supporting for this classification.

The inclusion of Iticocaris within Fontinalicaridinae. ScHMINKE (2010) formally established Parastenocaridinae Chappuis, 1940 and Fontinalicaridinae Schminke, 2010 within Parastenocarididae. In accordance with KARANOvIC \& COOPER (2011), this system is "overly simplistic", and Schminke (2010) failed to define the two proposed subfamilies by a clear set of morphological synapomorphies.

However, the Fontinalicaridinae is considered a monophyletic taxon as demonstrated by the two following autapomorphies: enp of female P3 lacking a terminal seta (appearing as a relatively short element with a rounded apex), and the shape of the female genital field (a roundish structure as broad as high). An additional diagnostic but plesiomorphic character is the clasping mechanism of the A1 of the male, in which segment 7 is not sickle-shaped and the mechanism involves the last three segments forming a coil with terminal segment 8 pointing laterally (SCHMINKE 2010; ipsis litteris). Such a coiled male A1 is a condition found only in Remaneicaris, and in the species assigned to the Fontinalicaridinae.

According to ScHMINKE (2010), the Parastenocaridinae may also be a monophyletic group as suggested by the spinule row located medially at the basis of male P4 enp and by the arrangement of the furcal setae (no gap between the outer setae I, II, III, and the dorsal seta VII). An additional apomorphic diagnostic character is the presence of a unique male A1 geniculation. While 
clasping the female, segments 5 and segment 7 of the male A1 form a functional unit. "Segment 5 is dilated and has an inner conical protrusion proximally, segment 7 is sickle-shaped (the distal inner corner being extended into an apophysis) and can, like the blade of a pocketknife, be folded back onto the fifth segment. In this position terminal segment 8 points medially" (SCHMINKE, 2010:345).
Schminke (2010) considered Remaneicaris as belonging to the Parastenocaridinae. However, we hypothesize that Remaneicaris is the basalmost group within the entire family, as evidenced by the presence of many plesiomorphies (CorgosinHo et al., 2007).

Iticocaris gen. nov. does not possess all the diagnostic characters shared by members of the presently known Fontinalicaridinae, but it can be easily

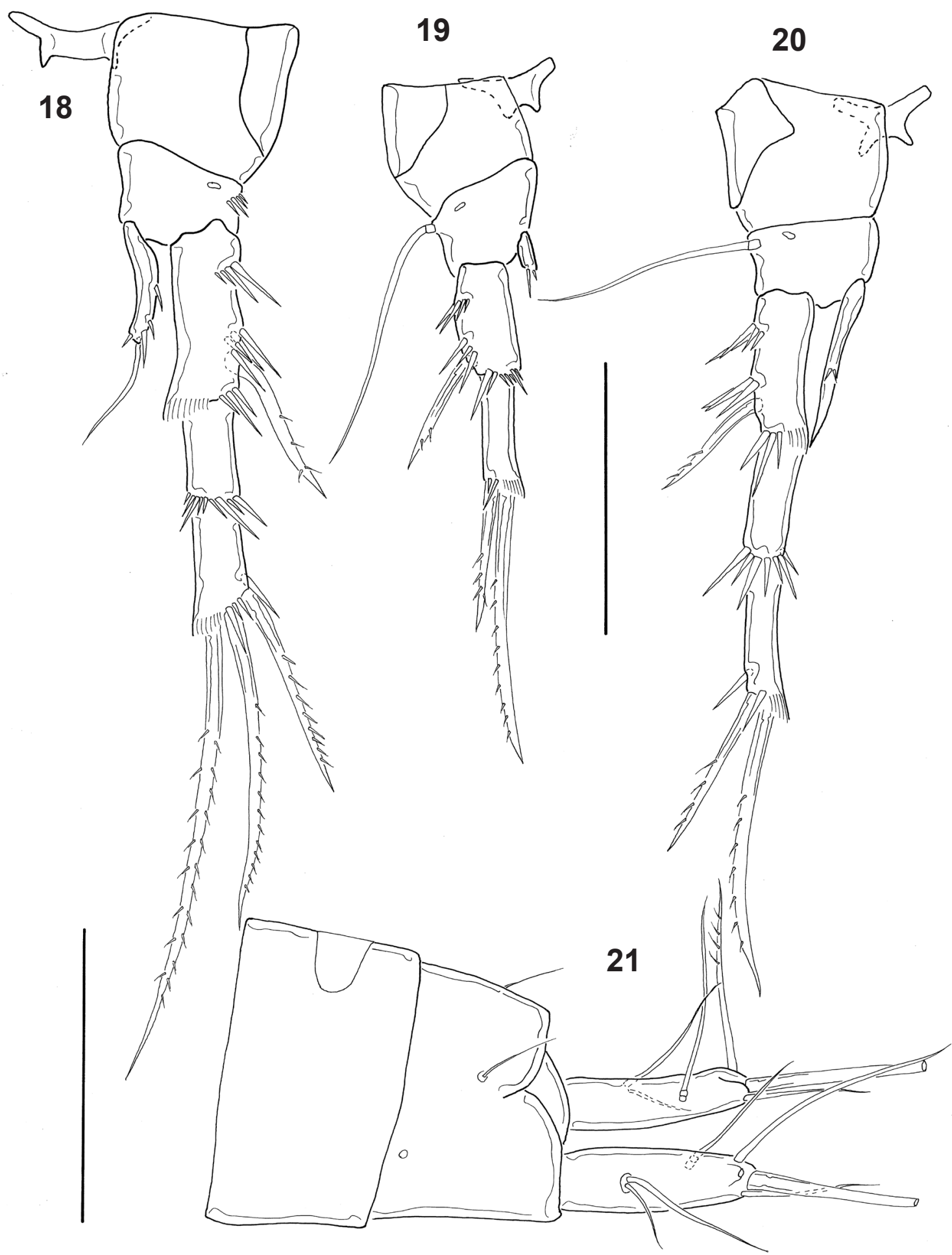

Figs 18-21. Iticocaris itica (Noodt, 1962), paralectotype, Noodt collection, Box 6, slide 7: 17, female P2; 18, P3; 19, P4; 20, telson with furca and preceding urosomite. Scale bars: Figs 18-20, $30 \mu \mathrm{m}$; Fig. 21, $75 \mu \mathrm{m}$. 
accommodated within this subfamily due to the presence of the same coiled type male A1, the reduced P3 enp of the female accompanied by the loss of its distal seta, and the roundish female genital field.

A critical analysis of Parastenocarididae groups of LANG (1948). A superficial comparison of LANG's (1948) system with SCHMinKE's (2010) proposed subfamilial division quickly shows that LANG's (1948) species groups of Parastenocarididae are supported by weak diagnostic characters, some based on observational errors or symplesiomorphies. The likely outcome of this is the establishment non-monophyletic groups.

A comparison of the Parastenocaris fontinalis group, as it was proposed by LANG (1948), with the list of species included in each subfamily by SCHMINKE (2010:350-352, Table 1) shows that not all species included by LANG (1948) within the Parastenocaris fontinalis group are closely related to each other. In fact, only Fontinalicaris fontinalis (Schnitter \& Chappuis, 1915) and Parastenocaris aquaeductus Chappuis, 1925 are clearly attributable to the subfamily Fontinalicaridinae. The remaining species, viz., Entzicaris entzi (Török, 1935), Pannonicaris aedes (Hertzog, 1938), and Parastenocaris similis Török, 1935 are typical Parastenocaridinae.

The problem in LANG's (1948) system of distantly related species composing artificial groups can also be observed in the group of Parastenocaris proserpina Chappuis, 1938, among the species of which Proserpinicaris nolli (Kiefer, 1938) and Lacustricaris budapestiensis (Török,1935) belong to the Parastenocaridinae whereas Proserpinicaris cantabrica (Chappuis, 1937), Proserpinicaris proserpina and Proserpinicaris phyllura (Kiefer, 1938) belong to the Fontinalicaridinae. Within the group of Parastenocaris minuta Chappuis, 1925, Pannonicaris pannonicus is the sole representative of the Fontinalicaridinae.

Astrict application of the system proposed by LANG (1948) to some genera, such as Simplicaris, Monodicaris, Kinnecaris, Asiacaris and Dussartstenocaris Karanovic \& Cooper, 2012 reveals that each genus can be accommodated within the Langian system. Simplicaris could be easily integrated within the Parastenocaris minuta group, Monodicaris within the $P$. brevipes group, Kinnecaris within P. muscicola group, Asiacaris could tentatively be included within the $P$. nana group and Dussartstenocaris within the $P$. fontinalis group instead of $P$. minuta group as proposed by KARANOvIC \& COOPER (2011)

Although it is possible that some of these genera will eventually prove to be junior synonyms of some JAKOBI's (1972) genera after a phylogenetic analysis at the generic level [classification of JAKOBI (1972) is based on an orbital system which similar complex structures are not considered a priori homologous to each other, but rather the result of convergence or parallelism within evolutionary trends (CORGOSINHO \&
Martínez Arbizu, 2005)], we regard it as an advance that authors have recently rejected Lang's system in favor of establishing a more stable one supported by clear diagnostic characters.

Rejection of Parastenocaris fontinalis group of LANG (1948). Iticocaris itica can be well accommodated within LANG's (1948) Parastenocaris fontinalis group on the basis of the 1-segmented P2 enp and the lack of sexual dimorphism of the P4. However, Martínez Arbizu (1997) regarded as useless these two diagnostic characters for the Parastenocaris fontinalis group. Within this group, even in Fontinalicaris fontinalis the $\mathrm{P} 4$ enp is sexually dimorphic. In fact, a sexually dimorphic enp in P4 enp is considered an autapomorphy of the Parastenocarididae, having being lost independently more than once within this family (Martínez Arbizu \& Moura, 1994). A 1-segmented P2 enp is a symplesiomorphy for all parastenocaridids (Martínez Arbizu \& Moura, 1994; Martínez Arbizu, 1997) and cannot be used to endorse the inclusion of any species within the Parastenocaris fontinalis group. The presence of a 2- segmented P2 enp in the group of Parastenocaris staheli Menzel, 1916 is doubtful (LANG, 1948).

Because of these difficulties, Martínez Arbizu (1997) revised Lang's Parastenocaris fontinalis group, removing from it the parastenocaridines Entzicaris entzi, Parastenocaris similis, and Pannonicaris aedes, with the remainder, namely Fontinalicaris fontinalis, F. meridionalis (Rouch, 1990) (previously F. fontinalis meridionalis), F. psammica (Songeur, 1961), and F. hispanica (Martínez Arbizu, 1997), comprising a new Parastenocaris fontinalis group, i.e. a new conception of Fontinalicaris. These species share the same construction of the male P4 enp, and their monophyly is also supported by the following autapomorphies (plesiomorphies in parenthesis): fused seta of male P4 enp with subordinate spinules only on outer margin (vs. P. aquaeductus Chappuis, 1925 and other species around P. kabiloides Enckell, 1969 have such ornamentation on both sides of the P4 enp); male P3 basis without row of spinules ( $v s$. with spinules, where the presence of such ornamentation is a symplesiomorphy of the family); male P3 exp portion of segment 1 without spinules on inner margin (vs. two spinules are present in P. aquaeductus and in the copepodite V of $P$. hispanica); male P4 exp 1 with row of spinules on inner margin subterminally inserted ( $v$ s. inserted distally in $P$. aquaeductus and in the copepodite V of $P$. hispanica); male $\mathrm{P} 3$ exp "apophysis" twice longer than wide ( $v s$. as long as wide in $P$. aquaeductus and in the copepodite $\mathrm{V}$ of $P$. hispanica); female P4 basis without spinules between exp and enp (vs. P. aquaeductus with row of spinules in this position).

The position of Martínez Arbizu (1997) has been strongly criticized by KARANOVIC (2005), who argued in favor of the Lang's system and KarANOvic \& LeE (2012), who considers the Fontinalicaris species F. 
hispanica and F. meridionalis as belonging to their newly revised Proserpinicaris (JАKOBI, 1972a), on the basis of phylogenetic analysis where some clear plesiomorphic characters are scored as apomorphies. According to Karanovic (2005) and Karanovic et al. (2012), Martínez Arbizu (1997) narrowed the Parastenocaris fontinalis group concept too much. However, Martínez Arbizu (1997) merely restricted it to the monophyletic group of species closely related to $F$. fontinalis. This author did not exclude the possibility that other monophyletic groups and, therefore, new genera, could be closely related to his concept of Fontinalicaris, and that these altogether could constitute a larger monophyletic unit within the Fontinalicaridinae. In other words, what Schminke (2010) now defines as Fontinalicaridinae (a monophyletic subfamily) is a potential source of new genera that are closely related to the Parastenocaris fontinalis group (Fontinalicaris) defined by MARTínEZ Arbizu (1997), but not directly related to any species currently comprising Fontinalicaris.

As the most recent word on the subject, SCHMINKE (2010) does not accept the genus Fontinalicaris as defined by Martínez Arbizu (1997), restricting it to the type species with its two subspecies Fontinalicaris fontinalis fontinalis (Schnitter \& Chappuis, 1915), and Fontinalicaris fontinalis borea (Kiefer, 1960). Here we accept the concept of MarTínez ArbizU (1997) instead.

On the basis of the above discussion on the Fontinalicaris "unit", it remains to be checked wheter Iticocaris itica can be accommodated into the genus Fontinalicaris as defined by Martínez Arbizu (1997). Iticocaris itica does not share any synapomorphy with Fontinalicaris fontinalis nor with Fontinalicaris sensu Martínez Arbizu (1997).

Rejection of the Parastenocaris proserpina group of LANG (1948). According to KARANOVIC (2005), Fontinalicaris hispanica is a typical member of the Parastenocaris proserpina group. By rejecting a close relationship of this species with $F$. fontinalis, KARANOVIC (2005) also rejected Martínez Arbizu's hypothesis (1997) in favor of Lang's system. Recently, KARANOviC \& Lee (2012) redefined the genus Proserpinicaris. However, their genus is basically supported by a plesiomorphy and is considered paraphyletic. Therefore, we reject this genus as it is currently defined.

The Parastenocaris proserpina group is another clear case of how the strict adoption of the Langian system can induce bias in the systematics of the Parastenocarididae, giving support to polyphyletic groups. We have argued above that the $P$. proserpina group is not monophyletic (with members belonging to both Fontinalicaridinae and Parastenocaridinae). Here we discuss the diagnostic characters proposed by LANG (1948), and in so doing, give support to MartínEZ Arbizu's (1997) system. This in turn provides an endorsement of our decision not to include Iticocaris itica in the Parastenocaris fontinalis group of LANG (1948).
Accordance to LANG (1948:1219) the P. proserpina group can be defined by the presence of two P4 "appendages" ("Anhangen") at the inner margin of basis in males, the outer of which is probably the enp. There are at least two problems with the LANG's (1948) diagnosis. The first is that there is a dubious condition to define the $P$. proserpina group since it is not absolutely clear which "appendage" represents the enp. The second problem is that the enp is the outer element in the fontinalicaridids Proserpinicaris proserpina, $P$. cantabrica and $P$. phyllura. The inner element in these species is a hyaline spinule on the basis between the enp and exp. This spinule is present in Fontinalicaris and at least other 25 species of the Fontinalicaridinae (SCHMINKe, 2010), including Fontinalicaris hispanica. In contrast, the enp is the inner element in the remaining representatives of the $P$. proserpina group, namely the parastenocaridids Lacustricaris budapestiensis and Proserpinicaris nolli. Presence of the hyaline spinule located between the enp and exp of Fontinalicaris hispanica is a synapomorphy of the Fontinalicaridinae. Within this subfamily, it becomes a shared plesiomorphic character (symplesiomorphy) and cannot be used to support any close relationship of Fontinalicaris hispanica and the species closely related to Proserpinicaris proserpina.

On the basis of these arguments, I. itica cannot be placed in the polyphyletic $P$. proserpina group.

Lack of dimorphism on P4 endopod. Within the Fontinalicaridinae, it seems that only a few species do not have a sexually dimorphic P4 enp [viz. Lacustricaris lacustris (Chappuis, 1957) from North America and $P$. matopoica Wells, 1964 from Rhodesia]. In the Neotropical region, no other known species is so modified. While the male P4 enp of Parastenocaris staheli seems already to represent a derived condition of the ground pattern observed for the females, the $\mathrm{P} 3$ morphology of this species precludes any close relationship with Iticocaris itica. In the absence of other potential synapomorphies with either of the species mentioned above, the absence of sexual dimorphism of the P4 enp is considered an autapomorphy for Iticocaris, as a result of heterochrony. With the exception of the species mentioned above and Dussartstenocaris idioxenos Karanovic \& Cooper, 2011, all the remaining Parastenocarididae that lack or show only weak dimorphism of the P4 enp belong to the Parastenocaridinae.

Relationships between Iticocaris gen. nov. and Brasilibathynellocaris. The inclusion of Iticocaris itica in the genus Brasilibathynellocaris might be supported by the shared presence of a very long apophysis on the male P3, strongly curved downwards and forming a cheliform forceps against the thumb. This feature might place I. itica as the first offshoot of Brasilibathynellocaris, while the absence of the following synapomorphies (Corgosinho et al., 2010) would preclude its inclusion any higher in that genus: exp- 1 of male $\mathrm{P} 4$ short, with an invagination on the proximal inner margin; presence of 2 strong spinules present on the anterior margin of 
the coxa of $\mathrm{P} 4$ in males; a hyaline cushion present on the inner margin of male P3 exp-1, and a hyaline margin present on the apophysis.

The male P3 morphology described above is uncommon in the Parastenocarididae; besides I. itica, a similar condition is found only in Brasilibathynellocaris species. However, in I. itica the P3 in adult males is 2-segmented, a character observed only in some adult males of Forficatocaris (A. Ahnert, unpubl. data), in a neotenic specimen of B. salvadorensis Noodt, 1962 and also in the copepodid $\mathrm{V}$ of this species (CORGOSInHo et al., 2010). This reduced segmentation is plausibly the result of post-displacement, with the concomitant retention of a neotenic structure in the adult. If so, it probably appeared independently in the evolutionary history of the Parastenocarididae, occurring in Brasilibathynellocaris (only in the copepodid V), Forficatocaris and Iticocaris gen. nov. It also appears in some Parastenocaridinae species, such as Parastenocaris savita Ranga Reddy, 2001 and P. mahanadi Ranga Reddy \& Defaye, 2007. However, a more parsimonious assumption is to consider a 2-segmented P3 exp as having appeared independently several times in the Parastenocarididae and thus constituting a homoplasic autapomorphy for I. itica.

The long, downward curved apophysis of I. itica must not be confused with the distal spine present on the apophysis of several parastenocaridids. The articulation present between the first enp and the apophysis in I. itica shows that these structures are not homologous. On the other hand, it strengthens the suggestion of a homology between the condition observed in I. itica and the sistergenus Brasilibathynellocaris, since a similar condition can be observed at least during the ontogenetic development of B. salvadorensis (CoRGosinHo et al., 2010).

Iticocaris itica could be hypothetically considered as the most derived species of Brasilibathynellocaris. However, the lack of shared apomorphies between I. itica and members of Brasilibathynellocaris (viz. $B$. paranaensis group and B. salvadorensis group, Corgosinho et al., 2010) does not give arguments for such a position into Brasilibathynellocaris.

The phylogenetic position of Iticocaris itica. The phylogenetic position of the South American fontinalicaridids is still unclear. However, it is very interesting that a group of species in South America, such as the species composing Brasilibathynellocaris and Siolicaris Jakobi, 1972, has lost the most proximal seta of the P5 of males and reduced or lost the seta II of the furca. We are not sure whether these transformations are synapomorphies for a South American group, for a larger group within the family or if they are the result of multiple origin. However, both losses are evident in Iticocaris gen. nov, as well. In order to arrive at a comprehensive hypothesis of the evolution of the South American parastenocaridids, we recommend focussing on the relationships between Iticocaris gen. nov. and the genera Brasilibathynellocaris and Siolicaris.
Acknowledgements. We would like to thank the Deutscher Akademischer Austausch Dienst "DAAD", the Fundação de Amparo à Pesquisa do Estado do Amazonas (FAPEAM), and the Forschungsinstitut Senckenberg for financial support of the senior author. We are indebted to the DZMB Senckenberg Forschungsinstitut and the Instituto Nacional de Pesquisas da Amazônia for logistical support during this work. This study would not have been possible without the examination of Dr. Wolfram Noodt's type material. We are especially indebted to Dr. Ahmed Ahnert, who curated Noodt's material after he passed away and placed it at our disposal for the present study, and to Dr. Janet Reid and Prof. Horst Kurt Schminke for their valuable comments on the manuscript.

\section{REFERENCES}

Ax, P. 1984. Das Phylogenetische System: Systematisierung der lebenden Natur aufgrund ihrer Phylogenese. Stuttgart, Gustav Fischer Verlag. 349p

Chappuis, P. A. 1942. Eine neue Methode zur Untersuchung der Grundwasser-fauna. Acta Scientiarum Mathematicarum et Naturalium 6:1-7.

Corgosinho, P. H. C. \& Martínez Arbizu, P. 2005. Two new interstitial species of Remaneicaris Jakobi 1972 from Ribeirão do Ouro River, Minas Gerais, Brazil, with a redefinition of the genus (Crustacea, Copepoda, Harpacticoida, Parastenocarididae). Senckenbergiana Biologica 85(2):147-162.

Corgosinho, P. H. C.; Martínez Arbizu, P. \& Santos-Silva, E. N. 2007. Three new species of Remaneicaris Jakobi, 1972 (Copepoda, Harpacticoida, Parastenocarididae) from the Ribeirão do Ouro River, Minas Gerais, Brazil, with some remarks on the groundpattern of the Parastenocarididae. Zootaxa 1437:1-28.

2010. Revision of Brasilibathynellocaris Jakobi, 1972 (Copepoda: Harpacticoida: Parastenocarididae) with redefinition of the genus. Zoological Journal of the Linnean Society 159:527-566.

Corgosinho, P. H. C.; Ranga Reddy, Y. \& Martínez Arbizu, P. 2012. Revision of the genus Siolicaris JAKOBI, with redescription of $S$. sioli (Noodt, 1963) and S. Jakobi (Noodt, 1963) from South America, and S. sandhya (Rango-Reddy, 2001) comb. nov. from India (Copepoda, Harpacticoida, Parastenocarididae). Zootaxa 3493:49-71.

Cottarelli, V.; Bruno, M. C. \& Berera, R. 2010. First record of Parastenocarididae from Thailand and description of a new genus (Copepoda: Harpacticoida). Journal of Crustacean Biology 30(3):478-494

Ferrari, F. D. \& Ivanenko, V. N. 2008. The identity of protopodal segments and the ramus of maxilla 2 of copepods (Copepoda) Crustaceana 81:823-835.

Galassi, D. M. P. \& De Laurentis, P. 2004. Towards a revision of the genus Parastenocaris Kessler, 1913: establishment of Simplicaris gen. nov. from groundwaters in central Italy and review of the $P$. brevipes-group (Copepoda, Harpacticoida, Parastenocarididae). Zoological Journal of the Linnean Society 140:417-436.

Glatzel, T. 1991. Neue morphologische Aspekte und die CopepodidStadien von Parastenocaris phyllura Kiefer (Copepoda, Harpacticoida). Zoologica Scripta 20(4):375-393.

Huys, R. \& Boxshall, G. A. 1991. Copepod evolution. London, The Ray Society. 468 p.

ICZN. 1999. International Code of Zoological Nomenclature. 4ed. London, International Trust for Zoological Nomenclature. 306p.

JAKOBI, H. 1972a. Trends (Enp. P4 Männchen) innerhalb der Parastenocarididen (Copepoda Harpacticoidea). Crustaceana 22:127-146.

1972b. Zur Kenntnis der Forficatocaris-Zoenose des Nhundiaquara (Paraná - Brasilien). Studies on Neotropical Fauna 7:239-251.

Karanovic, T. 2005. Two new subterranean Parastenocarididae (Crustacea, Copepoda, Harpacticoida) from Western Australia. Records of the Western Australian Museum 22:353-374.

2006. Subterranean copepods (Crustacea, Copepoda) from the Pilbara region in Western Australia. Records of the Western Australian Museum 70:1-239.

Karanovic, T. \& CoOper, S. J. B. 2011. Third genus of parastenocaridid copepods from Australia supported by molecular evidence (Copepoda, Harpacticoida). Studies on Freshwater Copepoda: a Volume in Honour of Bernard Dussart: 293-338. 
Karanovic, T. \& Lee, W. 2012. A new species of Parastenocaris from Korea, with a redescription of the closely related $P$. biwae from Japan (Copepoda: Harpacticoida: Parastenocarididae). Journal of Species Research 1(1):4-34.

Karanovic, T.; Cho, J.-L. \& Lee, W. 2012. Redefinition of the parastenocaridid genus Proserpinicaris (Copepoda: Harpacticoida), with description of three new species from Korea. Journal of Natural History 46:1573-1613.

LANG, K. 1948. Monographie der Harpacticiden. Vol I and II. Lund, Hakan Ohlssons Boktryckeri, 1. 683p.

Martínez Arbizu, P. 1997. Parastenocaris hispanica n. sp. (Copepoda: Harpacticoida: Parastenocarididae) from hyporheic groundwaters in Spain and its phylogenetic position within the fontinalis-group of species. Contributions to Zoology 66:215-226.

Martínez Arbizu, P. \& Moura, G. 1994. The phylogenetic position of the Cylindropsyllinae Sars (Copepoda, Harpacticoida) and the systematic status of the Leptopontiinae Lang. Zoologische Beiträge 35(1):55-77.

Noodt, W. 1962. Limnisch subterrane Copepoden der Gattung Parastenocaris Kessler aus Mittelamerika. Beiträge zur Neotropischen Fauna 2(3):223-248.

1972. Drei neue Parastenocaris aus Kolumbien (Crustacea Copepoda). 1. Mitteilung über kolumbianische GrundwasserCrustaceen. Studies on Neotropical Fauna 7:101-112.
REID, J. W. 1993a. The harpacticoid and cyclopoid copepod fauna in the cerrado region of central Brazil. 1. Species composition, habitats, and zoogeography. Acta Limnologica Brasiliensia 6:56-68.

. 1993b. The harpacticoid and cyclopoid copepod fauna in the cerrado region of central Brazil. 2. Community structures. Acta Limnologica Brasiliensia 6:69-81.

1995. Redescription of Parastenocaris brevipes Kessler and description of a new species of Parastenocaris (Copepoda: Harpacticoida: Parastenocarididae) from the U.S.A. Canadian Journal of Zoology 73:173-187.

Schminke, H. K. 1976. The ubiquitous telson and the deceptive furca. Crustaceana 30:292-300.

. 2008. First report of groundwater fauna from Papua New Guinea: Kinnecaris Jakobi, 1972 redefined (Copepoda, Harpacticoida, Parastenocarididae), and description of a new species. Crustaceana 81(10): 1241-1253.

2009. Monodicaris gen. n. (Copepoda, Harpacticoida, Parastenocarididae) from west Africa. Crustaceana 82(3):367378.

2010. High-level phylogenetic relationships within Parastenocarididae (Copepoda, Harpacticoida). Crustaceana 83(3):343-367.

WeLLS, J. B. J. 2007. An annotated checklist and keys to the species of Copepoda Harpacticoida (Crustacea). Zootaxa 1568:1-872. 